\title{
Abundance and vertical flux of Pseudo-nitzschia in the northern Gulf of Mexico
}

\author{
Quay Dortch ${ }^{1, *}$, Randy Robichaux ${ }^{1}$, Suzan Pool ${ }^{1}$, Dana Milsted ${ }^{1}$, Geoff Mire ${ }^{2}$, \\ Nancy N. Rabalais ${ }^{1}$, Thomas M. Soniat ${ }^{2}$, Greta A. Fryxell ${ }^{3}$, R. Eugene Turner ${ }^{4}$, \\ Michael L. Parsons ${ }^{4}$ \\ ${ }^{1}$ Louisiana Universities Marine Consortium, 8124 Highway 56, Chauvin, Louisiana 70344, USA \\ ${ }^{2}$ Department of Biological Sciences, Nicholls State University, Thibodaux, Louisiana 70310, USA \\ ${ }^{3}$ Department of Oceanography, Texas A\&M University, College Station, Texas 77843, USA \\ ${ }^{4}$ Department of Oceanography and Coastal Sciences, Louisiana State University, Baton Rouge, Louisiana 70803, USA
}

\begin{abstract}
Many species of the ubiquitous pennate diatom genus Pseudo-nitzschia have recently been discovered to produce domoic acid, a potent neurotoxin which causes Amnesic Shellfish Poisoning (ASP). Pseudo-nitzschia spp. were extremely abundant (up to $10^{8}$ cells $1^{-1}$; present in $67 \%$ of 2195 samples) from 1990 to 1994 on the Louisiana and Texas, USA, continental shelves and moderately abundant (up to $10^{5}$ cells $\mathrm{I}^{-1}$; present in $18 \%$ of 192 samples) over oyster beds in the Terrebonne Bay estuary in Louisiana in 1993 and 1994. On the shelf there was a strong seasonal cycle with maxima every spring for $5 \mathrm{yr}$ and sometimes in the fall, which were probably related to river flow, water column stability, and nutrient availability. In contrast, in the estuary there was no apparent seasonal cycle in abundance, but the time series of data is relatively short and the environment highly variable. At one site on the shelf, where sediment traps were deployed from spring to fall and sampled at frequent intervals in both 1990 and 1991, approximately $50 \%$ of the Pseudo-nitzschia spp. cells present in the water sank into sediment traps. Pseudo-nitzschia spp. were also abundant in surficial sediments. The species of Pseudo-nitzschia present during this study were not routinely identified with the methods employed. However, toxin-producing $P$. multiseries has been identified previously from Galveston Bay, Texas, and cells from a bloom on the shelf in June 1993 were identified by scanning electron microscopy as $P$. pseudodelicatissima, which is sometimes toxic. Although there have been no known outbreaks of ASP in this area, historical data suggests that Pseudo-nutzschia spp. abundance may have increased on the shelf since the 1950s. It is hypothesized that the increase is due to doubling of the nutrient loading from the Mississippi and Atchafalaya rivers and increased eutrophication on the shelf.
\end{abstract}

KEY WORDS: Pseudo-nitzschia Gulf of Mexico Harmful algal bloom

\section{INTRODUCTION}

A group of common coastal diatoms from the genus Pseudo-nitzschla have recently been found to contain a potent neurotoxin, domoic acid (summarized in Villac et al. 1993b). A wide range of organisms, such as mussels, oysters, razor clams, anchovies, smelt, Dungeness crabs or rock crabs, concentrate domoic acid in their stomach contents and/or body tissue by direct or indirect consumption of Pseudo-nitzschia spp. (Buck et al.

-E-mail: qdortch@lumcon.edu
1992, Fritz et al. 1992, Drum et al. 1993, Garrison \& Walz 1993, Horner et al. 1993, Langlois et al. 1993, Roelke 1993, Work et al. 1993, Wood et al. 1994). From these organisms it can be passed on to higher trophic levels such as humans or marine birds (Villac et al. 1993b).

The toxicity of Pseudo-nitzschia multiseries (formerly Nitzschia pungens var. multiseries, Hasle 1995) was first demonstrated when 107 people became ill and 3 died from eating mussels cultured on Prince Edward Island, Canada (Bates et al. 1989, Todd 1993). Since one of the characteristic symptoms is permanent short-term memory loss, the syndrome has been called 
Amnesic Shellfish Poisoning (ASP). Subsequently, seabird deaths of the coast of California (USA) in 1991 and human illness after consuming razor clams in Washington State (USA) were related to the occurrence of high numbers of Pseudo-nitzschia australis (Buck et al. 1992, Fritz et al. 1992, Horner \& Postel 1993, Work et al. 1993). Several other species of Pseudo-nitzschia produce domoic acid, but not all species nor all clones of sometimes toxic species produce it (Fryxell et al. 1990, 1991, Martin et al. 1990. Villac et al. 1993a, b, Lundholm et al. 1994) and production may be dependent on environmental conditions (Bates et al. 1991, Bates \& Douglas 1993, Lewis et al. 1993, Smith et al. 1993, Pan et al. 1996a, b). Thus, the widespread occurrence of potentially toxic Pseudonitzschia spp. poses a significant potential human health problem and it is essential to determine the distribution of Pseudo-nitzschia spp. and the environmental factors which control them in order to predict toxic outbreaks
During routine sampling for other purposes it was observed that Pseudo-nitzschia spp. were abundant in the water column, sediment traps, and surficial sediments on the Louisiana (USA) continental shelf in an area influenced by the Mississippi River (Dortch et al. 1992). Sampling on the Louisiana and Texas shelf was continued, so that there is now a 5 yr time series of data. Because toxic forms of Pseudo-nitzschia were also identified in Galveston Bay (Fryxell et al. 1990, 1991), additional sampling was begun at 3 estuarine locations with extensive oyster beds, for which there are now approximately $1.5 \mathrm{yr}$ of data.

Harmful algal blooms (HABs) have become a major problem in the coastal waters of many countries, with serious economic and human health consequences. A major need is to 'determine and parameterize the environmental factors that govern the initiation, growth, maintenance, dissipation and impact of HABs' (Anonymous 1995, p. 4), but this has been difficult due to the sporadic and ephemeral nature of their occurrence.

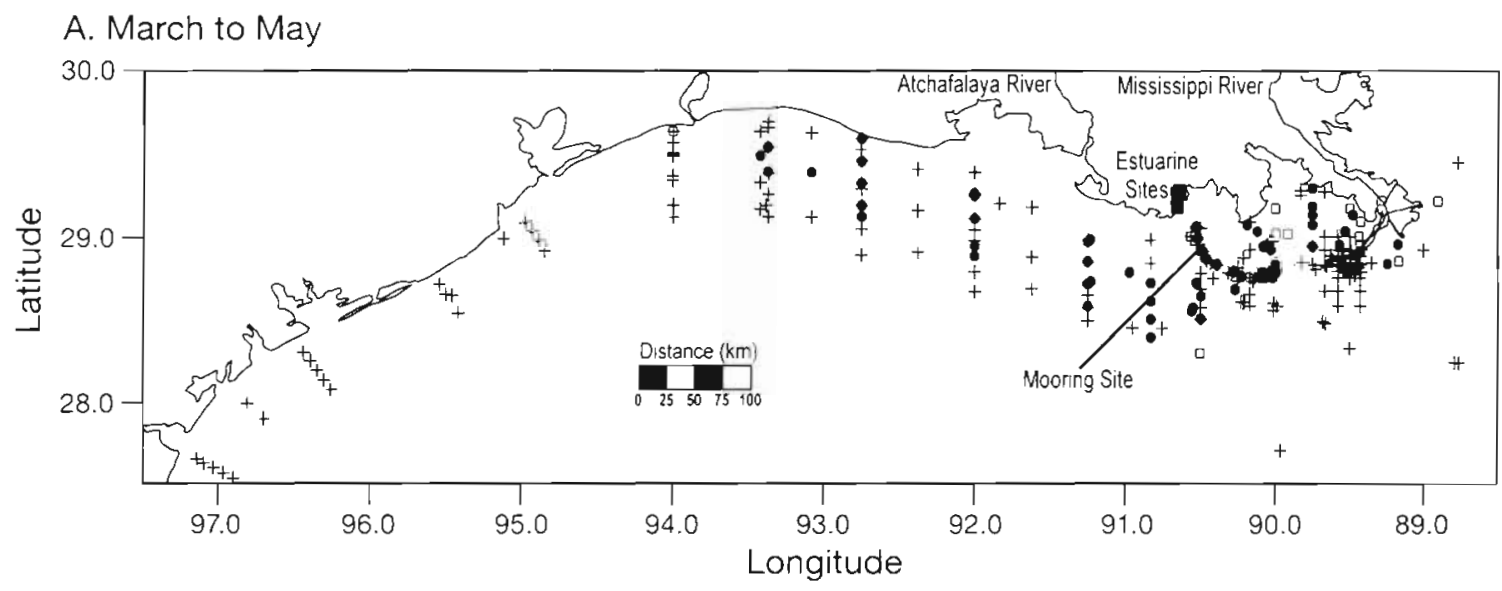

\section{B. June to October}

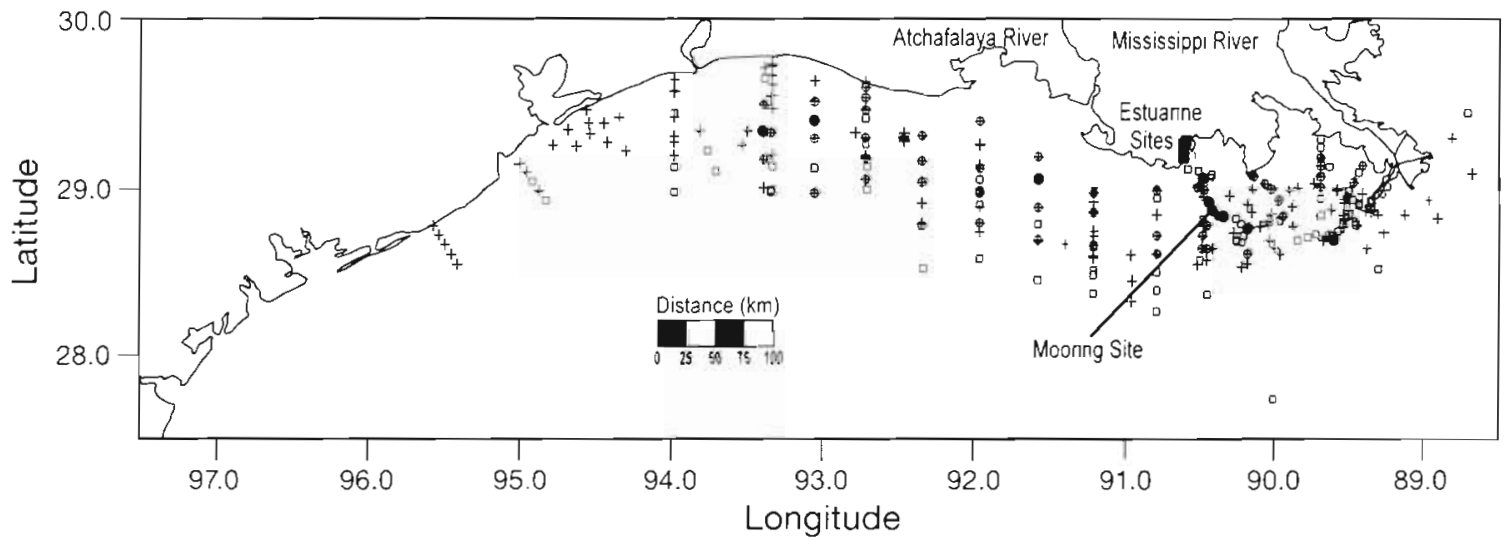

Fig. 1. Pseudo-nitzschia spp. Composite seasonal distribution maps along the Louisiana/Texas shelf. (A) March to May, $\mathrm{n}=335$; $\%$ frequency [number of samples with Pseudo-nitzschia spp. (total number of samples) ${ }^{-1} \times 100$ ] $=92.2$. $(B)$ June to October. $\mathrm{n}=502 ; \%$ frequency $=53.6$. (a) Stations at which Pseudo-nitzschia spp. were never observed, (t) stations at which $P_{\text {seudo- }}$ nitzschia spp. were present but numbers were $<10^{6}$ cells $1^{-1}$, ( ) stations at which Pseudo-nutzschia spp. abundance $>10^{6}$ cells $1^{-1}$ 
Clearly, Pseudo-nitzschia spp, are abundant in the northern Gulf of Mexico and, as a result of the influence of the Mississippi River and the proximity of the oligotrophic Gulf of Mexico, Louisiana and Texas coastal waters experience extreme ranges of all environmental variables. Surface salinities can vary from 0 to $>36 \%$ within relatively short distances, horizontally. Vertically, salinity differences are also often quite large, so that except in very shallow areas, in the winter, or in areas distant from the Mississippi River the region is also characterized by an extremely stable water column. Dissolved inorganic nitrogen (DIN) and silicate concentrations often exceed $100 \mu \mathrm{M}$ in or near the mouth of the Mississippi River, but drop to low, and sometimes undetectable, concentrations within short distances $(<100 \mathrm{~km})$. Due to the wide range of environmental conditions and frequent occurrence of Pseudonitzschia spp., this is an ideal area for examining the relationship between abundance and environmental factors.

This report describes the spatial and temporal variability of Pseudo-nitzschia spp. abundance and the temporal variability of Pseudo-nitzschia spp. vertical flux into sediment traps and abundance in surficial sediments, and begins to examine the environmental factors which influence Pseudo-nitzschia spp. distributions.

\section{METHODS}

Field sampling. Cruises were conducted along the Louisiana/Texas, USA, shelf from 1990 to 1994 (Fig. 1), as outlined in Table 1. Eight cruises, spanning 3 seasons, focused solely on the Mississippi River plume (MR plume, Table 1) and only a few samples were taken west of the Atchafalaya River. Six cruises traversed the Louisiana shelf between Southwest Pass of the Mississippi River and the Louisiana/Texas border (LA shelf); all but 1 cruise was in the middle of summer. Four cruises covered the western half of the Louisiana shelf (from slightly east of the Atchafalaya river) and approximately half of the Texas shelf (LA/TEX shelf), focusing on the extended plumes of the Mississippi and Atchafalaya Rivers and the coastal current. Finally, from 1990 to 1994, an offshore transect through an area of persistent bottom water hypoxia (Hypoxia transect; Rabalais et al. 1991, 1992, 1994) was made approximately monthly. In 1990 and 1991 samples were taken at 5 stations, including a station with an instrument and sediment trap mooring (see below), and from 1992 to 1994 samples were taken only at the station with the mooring. Sampling was conducted at the mooring location whenever possible on other cruises or when servicing the mooring, so data from this location represent the most detailed time series. Water samples were

Table 1. Cruises on the Louisiana/Texas continental shelf. See 'Methods: field sampling' for explanation of sampling location Hydrographic, nutrient, and chlorophyll data are contained in the data sources. N. N. Rabalais, R. E. Turner \& W. J. Wiseman Jr unpubl. (Rabalais et al. unpubl.) data are deposited with the NOAA Nutrient Enhanced Coastal Ocean Productivity (NECOP) Data Management Program (NDMP; Hendee 1994) and the National Oceanographic Data Center (NODC). N. N. Rabalais \& R. E Turner unpubl. data are deposited with NODC. • Phytoplankton data deposited in NDMP and NODC; " data deposited in NODC

\begin{tabular}{|c|c|c|c|}
\hline Date & Sampling location & Number of samples & Data source \\
\hline Jul-Aug 1990 & MR plume & $80^{\circ}$ & Hitchcock \& Whitledge (1992) \\
\hline Jul 1990 & LA shelf & $88^{\circ}$ & Rabalais et al. (unpubl.) \\
\hline Aug 1990 & MR plume & 66 & Rabalais et al. (unpubl.) \\
\hline Oct 1990 & MR plume & 46 & Toon \& Dagg (1991) \\
\hline 18 Mar-16 Nov 1990 & Hypoxia transect & $125^{\circ}$ & Rabalais et al. (unpubl.) \\
\hline Mar 1991 & MR plume & $77^{\circ}$ & Hitchcock \& Whitledge (1992) \\
\hline Jul 1991 & LA shelf & $94^{\circ}$ & Rabalais et al. (unpubl.) \\
\hline Sep 1991 & MR plume & 50 & Toon \& Dagg (1992a) \\
\hline 2 Feb-7 Dec 1991 & Hypoxia transect & $119^{\circ}$ & Rabalais et al. (unpubl.) \\
\hline Apr 1992 & LA/TEX shelf & $79 \cdot$ & Rabalais \& Turner (unpubl.) \\
\hline May 1992 & MR plume & $116^{\circ}$ & Toon \& Dagg $(1992 \mathrm{~b})$ \\
\hline Jul 1992 & LA shelf & $123^{\circ}$ & Rabalais et al. (unpubl.) \\
\hline Oct 1992 & LA/TEX shelf & $79^{*}$ & Rabalais \& Turner (unpubl.) \\
\hline 23 Feb-27 Oct 1992 & Hypoxia transect & $63^{\circ}$ & Rabalais et al. (unpubl.) \\
\hline Apr 1993 & MR plume & $74^{\circ}$ & Toon \& Dagg (1993) \\
\hline Apr 1993 & LA/TEX shelf & $93 \cdots$ & Rabalais \& Turner (unpubl.) \\
\hline Apr 1993 & LA shelf & $138^{\circ}$ & Rabalais et al. (unpubl.) \\
\hline Jul 1993 & LA/TEX shelf & $130^{\cdots}$ & Rabalais \& Turner (unpubl.) \\
\hline Jul 1993 & LA shelf & $124^{\circ}$ & Rabalais et al. (unpubl.) \\
\hline 19 Mar-18 Nov 1993 & Hypoxia transect & $74^{\circ}$ & Rabalais et al. (unpubl.) \\
\hline Apr 1994 & MR plume & $120^{\cdots}$ & Rabalais \& Turner (unpubl.) \\
\hline 25 Jan-20 Oct 1994 & Hypoxia transect & $43^{\circ}$ & Rabalais et al. (unpubl.) \\
\hline
\end{tabular}


usually obtained with Niskin bottles, after selecting appropriate depths based on hydrographic data obtained with a CTD (either Seabird SBE or Hydrolab Surveyor II or 3). However, due to the extreme vertical gradients in this region, surface samples were often taken with a plastic bucket. Nutrient, chlorophyll a, and suspended particulate matter (SPM) concentrations were measured on the same samples as the phytoplankton. Chlorophyll a was measured fluorometrically after filtration onto a Whatman GF/F filter and extraction with 40:60 DMSO:90\% acetone, as modified from Parsons et al. (1984). Nitrate, nitrite, ammonium, silicate, and phosphate were measured using either a Technicon AutoAnalyzer II or an Alpkem RFA/2 Rapid Flow Analyzer. When possible, samples were analyzed on board ship, but if necessary they were frozen and analyzed later in the lab. SPM was measured gravimetrically after filtration onto weighed Whatman GF/F filters.

Sediment traps, designed according to Prior et al. (1987), were deployed on a mooring with other instruments (Rabalais et al. 1992, 1994, Qureshi 1995) at a station in $20 \mathrm{~m}$ water depth in the center of a region where bottom water hypoxia is often observed in the summer (Fig. 1). Sediment trap data were analyzed only for 1990 and 1991. One trap was mounted at 5 or $7 \mathrm{~m}$ (depending on the year), above the usual location of the pycnocline (approx. $10 \mathrm{~m}$ ), and the other was mounted in the lower water column where hypoxia develops in the summer (at 15 or $16 \mathrm{~m}$, depending on the year). Weather permitting, the traps were serviced by divers at time intervals ranging from 1 to 3 wk. In 1990 the traps contained brine (45\%) and in 1991 they contained brine and $2.0 \%$ glutaraldehyde. Surficial sediments and overlying water were obtained from syringe cores taken either by divers or from box cores with overlying water still present.

Sampling in the Terrebonne Bay estuary over 3 oyster beds (Fig. 1) was conducted weekly from January 28, 1993 until December 29, 1994, with a hiatus from April 1, 1993 to August 26, 1993. The waters were quite shallow $(0.3$ to $1 \mathrm{~m})$ and generally well mixed, so that only 1 sample was taken on each date at each site using a hand-operated peristaltic pump with the intake located just above the oyster bed. Salinity was measured with a Reichert refractometer.

Phytoplankton identification and enumeration. Phytoplankton in the water were preserved in $0.5 \%$ glutaraldehyde and refrigerated for 1 to $24 \mathrm{~h}$. The samples were size-fractionated by filtration onto $0.2,3$, and $8 \mu \mathrm{m}$ polycarbonate filters, with $0.03 \%$ proflavine hemisulfate used to stain the latter 2 fractions, and then the filters were mounted in immersion oil (Murphy \& Haugen 1985, Shapiro et al. 1989). The 0.2 to $3 \mu \mathrm{m}$ fraction was counted immediately on board ship, the
3 to $8 \mu \mathrm{m}$ fraction was counted immediately if possible or otherwise refrigerated and counted within several days of returning. The slide with the $>8$ um fraction was frozen and counted later. All samples were counted using an Olympus BH2-RFCA epifluorescence microscope (EFM) with blue and green excitation light, and, when necessary, transmitted light. The phytoplankton were identified to the nearest possible taxon. As described in detail by Buck et al. (1992), the EFM is not usually used for enumerating the entire size range of phytoplankton, but diatoms can certainly be identified to the genus and often species level. In this case the genus Pseudo-nitzschia was readily identified, but not the individual species, which usually require scanning electron microscopy (SEM).

Sediment trap material was split up to 5 or 6 times in a small Folsom Plankton Splitter immediately after collection. One of the splits was preserved with $2.5 \%$ glutaraldehyde and stored in a refrigerator. Samples were later split between 1 and 11 more times, depending on the amount of material present. Slides were made on an aliquot of the last split and counted in exactly the same manner as for the water column phytoplankton, except that in 1991 live and dead cells were distinguished on the basis of cell contents which were stained with proflavine. Chains of Pseudonitzschia were readily distinguished, but single cells were more problematic. The counts reported include only those single cells which were likely to be Pseudonitzschia and may be an underestimate.

The top $1 \mathrm{~cm}$ of water and the top $2 \mathrm{~mm}$ of sediment were removed from syringe cores using a core extruder. The sample was diluted to $20 \mathrm{ml}$ in filtered seawater, made up to $2.5 \%$ glutaraldehyde, and stored in the refrigerator. The samples were split in a Folsom Plankton Splitter and slides were made and counted in the same manner as the sediment trap samples. Because short-term sedimentation rates are seasonally extremely variable (B. M. McKee unpubl. data), the time over which the top $2 \mathrm{~mm}$ was deposited is unknown and it is not possible to calculate flux to the sediment. The surficial sediment data are reported as cells area ${ }^{-1}$ and cannot be compared directly with fluxes into the sediment traps except when the data are expressed as \% abundance.

Samples were collected for species identification during a Pseudo-nitzschia bloom in June 1993. Preserved samples were centrifuged, the frustules cleaned using nitric acid in a boiling water bath, and identified using SEM.

Statistics. Normality of the data was determined based on a consensus of results from normal probability plots, frequency histograms, measures of skewness and kurtosis, chi-squared tests, and the Kolmogorov-Smirnov 1-sample tests. Pseudo-nitzschia spp. 
abundance data were often not normally distributed and sometimes could not be transformed to fit a normal distribution, due to the number of samples in which no Pseudo-nitzschia spp. were present (approx. 30\% overall). Several approaches were taken in order to report results and comparisons in a statistically appropriate manner when the data were not normally distributed. Medians are reported as well as means and standard deviations (e.g. see Tables 3 \& 4). Nonparametric tests were used when necessary, as indicated in the text. Results were considered significant when $p<0.05$. Significant figures are reported according to Sokal \& Rohlf (1969).

\section{RESULTS}

\section{Abundance and taxonomy}

Pseudo-nitzschia spp. were observed, at some time, everywhere on the Louisiana/Texas shelf (Fig. 1). The maximum concentration exceeded $10^{8}$ cells $\mathrm{l}^{-1}$ (Table 2 ), and concentrations $>10^{6}$ cells $\mathrm{l}^{-1}$ were not unusual ( $7.2 \%$ of samples). Pseudo-nitzschia spp. were present, at some level, in almost $70 \%$ of samples collected on the shelf. They made up a large fraction (16\%) of the diatoms (Table 2), which were the dominant group in terms of biomass (Dortch 1994)

Pseudo-nitzschia spp. were present, but much less abundant, in the Terrebonne Bay estuary. The maximum cell concentration was 3 orders of magnitude lower in the estuary in comparison with the shelf (Table 2). While Pseudo-nitzschia spp. cells were present in $18 \%$ of samples, their abundance relative to other diatoms was low $(<1 \%)$. However, the period of study was much shorter in the estuary than on the shelf, so that the full range of variation in the estuary is not known.

Much of the sampling on the shelf was conducted before the importance of Pseudo-nitzschia was widely known. Thus, no systematic effort was made to identify Pseudo-nitzschia to the species level. However, surface samples from a bloom at the mooring site on May
23, $1993\left(7.85 \times 10^{6}\right.$ cells $\left.^{-1}\right)$ were digested to remove organic matter, leaving cleaned frustules, and examined by SEM. The species was identified as Pseudonitzschia pseudodelicatissima (Fig. 2).

\section{Temporal and spatial variation on the shelf}

The best temporal coverage was at the mooring site, which was sampled approximately monthly at 4 depths for 5 yr (Fig. 3, Table 3). Despite considerable variability (Fig. 3), there were significant differences in Pseudo-nitzschia spp. abundance between the seasons both in the upper and lower layers (Kruskal-Wallis test). The only seasons for which the Pseudo-nitzschia spp. abundances are not significantly different from each other (Mann-Whitney $U$-test) are winter-fall in the upper layer and winter-spring and winter-fall in the lower layer, probably because there are so few data in winter (Table 3). Thus, the annual maximum in Pseudonitzschia spp. abundance occurred in spring, a minimum was observed in summer and a second peak occurred in the fall (Table 3). Composite surface maps indicate that the seasonal difference in abundance was apparent across the entire Louisiana/Texas shelf (Fig. 1). The greatest likelihood of encountering high numbers of Pseudo-nitzschia spp. $\left(>10^{6}\right.$ cells $\left.\mathrm{l}^{-1}\right)$ was in the spring when it was present most often in surface samples (Fig 1A). High concentrations were observed less often in the summer/fall months and they were not present in as many samples (Fig. 1B). The \% abundance of Pseudo-nitzschia spp. relative to total diatoms was greatest in spring and fall (Table 3 ). The fall maximum in \% abundance occurred because total diatoms decreased but Pseudo-nitzschia spp. did not.

Composite surface maps also show that Pseudonitzschia spp. were widely distributed throughout the Louisiana/Texas coastal zone (Fig. 1). High cell concentrations appeared to occur in the areas directly influenced by the Mississippi and Atchafalaya rivers and were not found farther to the south along the Texas coast, but this may have been a result of de-

Table 2. Pseudo-nitzschia spp. Summary of abundance in the Louisiana/Texas shelf and Terrebonne Bay estuary. \% Frequency: number of samples with Pseudo-nitzschia > 0/total number of samples; n: tota! number of samples. \% Abundance: number of Pseudo-nitzschia spp./total number of diatoms for samples with number of Pseudo-nitzschia spp. >0; n: number of samples with Pseuso-nitzschia spp. $>0$

\begin{tabular}{|c|c|c|c|c|}
\hline \multirow{2}{*}{ Area } & \multirow{2}{*}{$\begin{array}{c}\text { Maximum } \\
\text { concentration (cells } \text { L }^{-1} \text { ) }\end{array}$} & \multirow{2}{*}{$\%$ Frequency } & \multicolumn{2}{|c|}{$\%$ Abundance } \\
\hline & & & Range & Mean \\
\hline LA/TEX shelf & $1.02 \times 10^{8}$ & $\begin{array}{c}66.7 \\
\mathrm{n}=2195\end{array}$ & $\begin{array}{r}0.01-100 \\
n=1389\end{array}$ & 16.5 \\
\hline $\begin{array}{l}\text { Terrebonne Bay } \\
\text { estuary }\end{array}$ & $1.09 \times 10^{5}$ & $\begin{array}{c}18.2 \\
n=192\end{array}$ & $\begin{array}{l}0.01-4.67 \\
n=35\end{array}$ & 0.4 \\
\hline
\end{tabular}




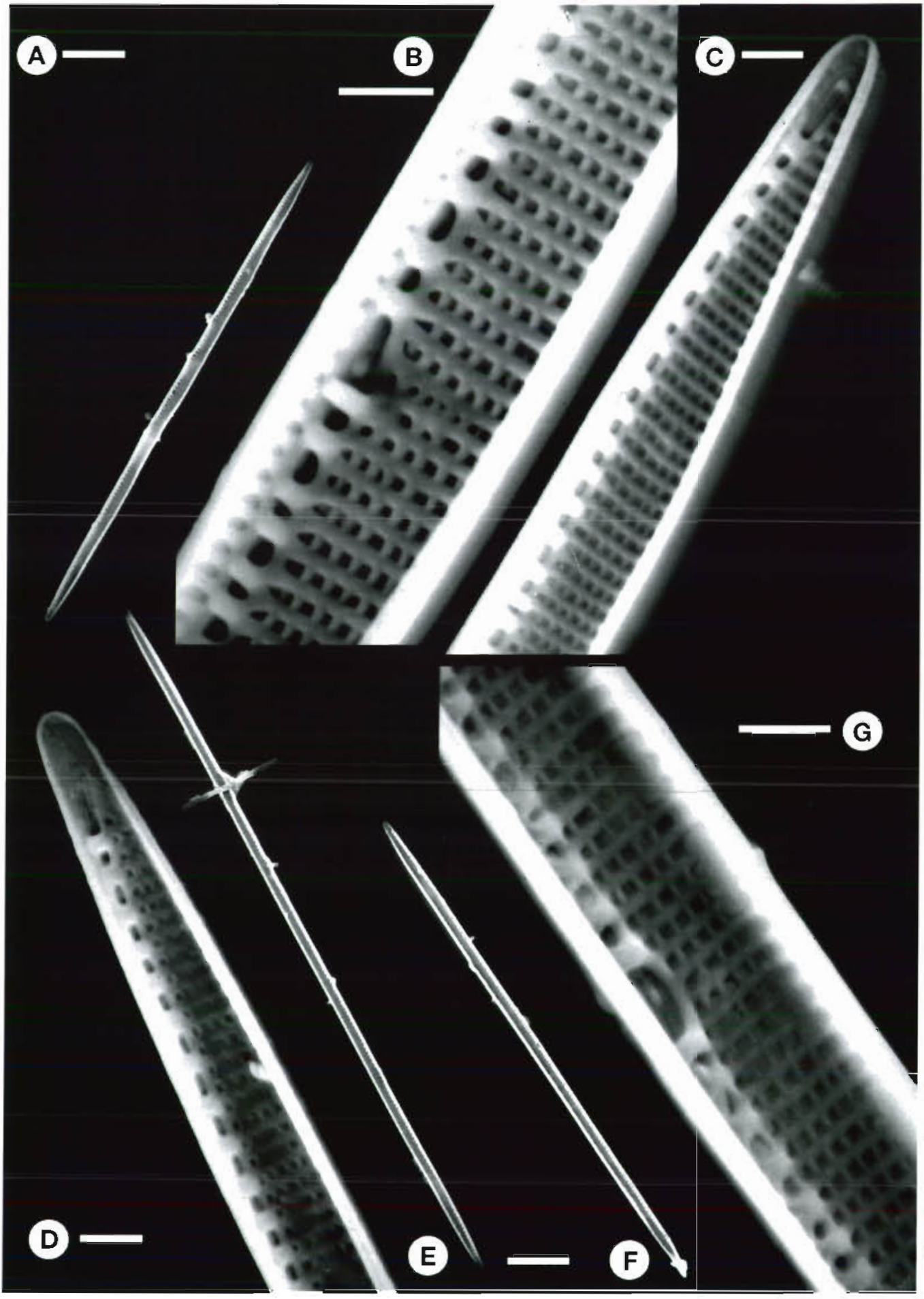

Fig. 2. Pseudo-nitzschia. Scanning electron micrographs from surface water sample taken during a bloom at the mooring site, June 23, 1993. All are inside views with siliceous arches (fibulae) overlying slit or raphe at juncture of mantle and valve face on left, except where noted. Note uniformity in width and shape within 1 species, but not in length. (A) P. pseudodelicatissima, orientation of whole valve, $86 \mu \mathrm{m}$ in length, scale bar $=10 \mu \mathrm{m}$. (B) Detail of central area of same valve showing wider distance between 2 central fibulae and square appearance of pores in striae, scale bar $=1 \mu \mathrm{m}$. (C) Tapered pole of same valve, showing terminus of raphe, scale bar $=1 \mu \mathrm{m}$. (D) P. pseudodelicatissima, obljque view of pole of longer valve showing slit in raphe running under fibulae, scale bar $=1 \mu \mathrm{m}$. (E) Orientation of same valve, $122 \mu \mathrm{m}$ in length, scale bar $=10 \mu \mathrm{m}$. (F) $P$. pseudodelicatissima, orientation of valve, raphe on nght, $88.5 \mu \mathrm{m}$ in length, same scale as $E$. (G) Detail of central area of same valve, showing vertical nature of mantles, central nodulus between the origins of the 2 raphe systems, typical valve structure, scale bar $=1 \mu \mathrm{m}$ 
Fig. 3. Pseudo-nitzschia spp. Time series of abundance at the mooring site from 1990 to 1994 . Upper and lower layer indicate samples above and below $10 \mathrm{~m}$, the approximate depth of the pycnocline when the water column is stratified. $\mathrm{n}=287, \%$ frequency (see Fig. 1) $=68.3 . \quad Y$-axis $=$ abundance +1

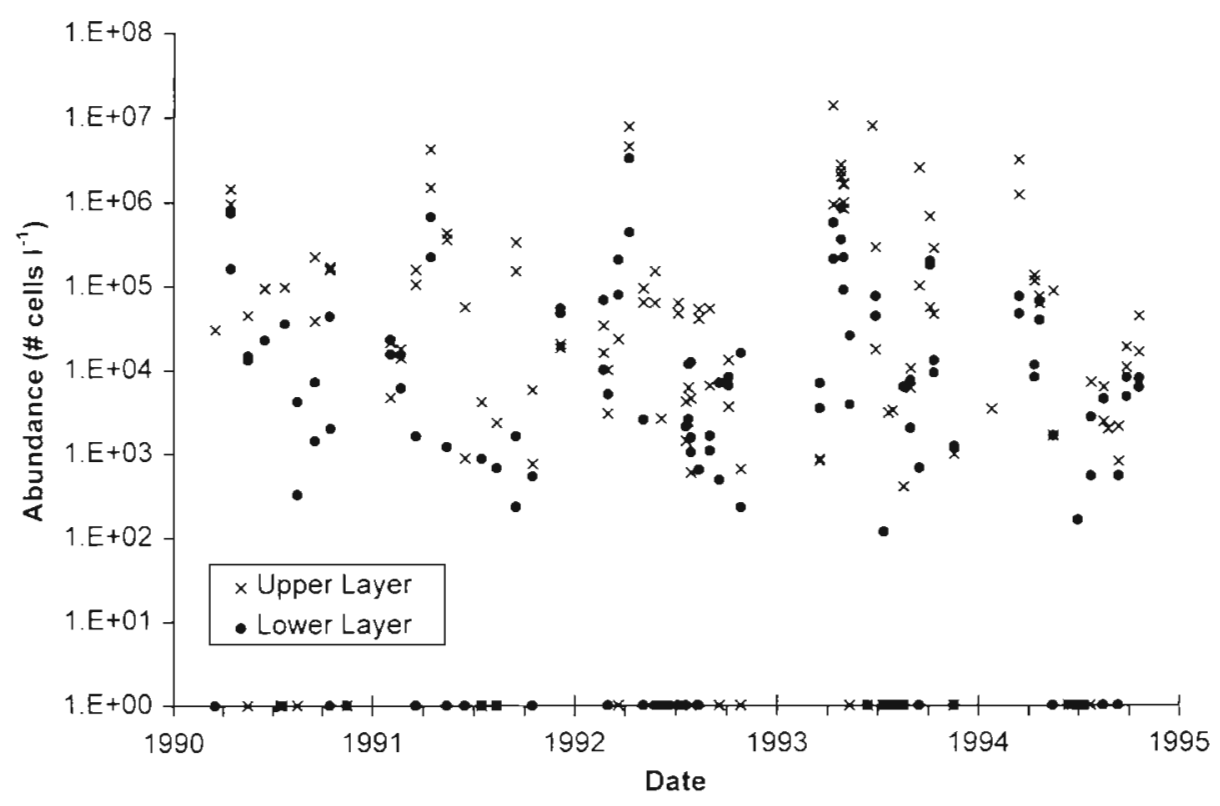

creased sampling density. For any given cruise, the distribution of Pseudo-nitzschia spp. was quite patchy, with little similarity between cruises even in the same seasons (data not shown).

Pseudo-nitzschia spp. were often abundant in bottom waters. In fact, the highest concentration observed (Table 2) was in a near-shore bottom sample $(10.5 \mathrm{~m})$ on April 12, 1994. In these shallow, turbid shelf waters, the euphotic zone is often $<5 \mathrm{~m}$, although it is possible for it to be as deep as $20 \mathrm{~m}$ (R. E. Turner pers. comm.). At those stations with Pseudo-nitzschia spp. in both the upper and lower layers, the concentrations in the lower layer were positively and significantly related to the concentrations in the surface layer. Thus, it seems likely that such high numbers are usually due to sinking rather than in situ growth.

\section{Vertical flux of Pseudo-nitzschia spp. on the shelf}

Pseudo-nitzschia spp. often comprised a large portion of the diatoms which were counted in sediment trap material at both depths and in surficial sediments in 1990 and 1991 (Table 4). Because diatoms made up the largest fraction of the directly sedimenting phytoplankton biomass (Dortch et al. 1992), Pseudonitzschia spp. contributed substantially to the vertical flux of phytoplankton. There was selective sinking of Pseudo-nitzschia into traps in both 1990 and 1991, as indi- cated by the significantly different median \% abundance in the water column and traps (Mann-Whitney $U$-test). Although the \% abundance was lower in surficial sediments than traps, the difference was only significant in 1991 (Student's $t$-test).

It is possible to distinguish between apparently dead cells, lacking contents, and living cells, with stainable contents, using epifluorescence microscopy. By these criteria approximately $90 \%$ of the Pseudo-nitzschia spp. cells in the traps in 1991 were dead (Table 4). Moreover, most of the Pseudo-nitzschia spp. cells in
Table 3. Pseudo-nitzschia spp. Seasonal variation in abundance (cells $\mathrm{l}^{-1}$ ) and $\%$ abundance [number of Pseudo-nitzschia (number of diatoms) ${ }^{-1} \times 100$ ) in the water at the mooring site. n: number of samples. Seasons based on changes in water column structure and frequency of mixing events. See Fig. 3 for description of upper and lower water layers

\begin{tabular}{|c|c|c|c|c|c|}
\hline \multirow[t]{2}{*}{ Season } & & \multicolumn{2}{|c|}{ Abundance } & \multicolumn{2}{|c|}{$\%$ Abundance } \\
\hline & & Upper & Lower & Upper & Lower \\
\hline $\begin{array}{l}\text { Spring } \\
\text { (Mar-May) }\end{array}$ & $\begin{array}{l}\text { Mean } \\
\text { Median } \\
\mathrm{SD} \\
\mathrm{n}\end{array}$ & $\begin{array}{c}1.24 \times 10^{6} \\
1.31 \times 10^{5} \\
2.49 \times 10^{6} \\
43\end{array}$ & $\begin{array}{c}2.11 \times 10^{5} \\
2.02 \times 10^{4} \\
5.42 \times 10^{5} \\
40\end{array}$ & $\begin{array}{c}17.1 \\
5.2 \\
25.4 \\
39\end{array}$ & $\begin{array}{c}19.7 \\
11.0 \\
25.4 \\
36\end{array}$ \\
\hline $\begin{array}{l}\text { Summer } \\
\text { (Jun-Aug) }\end{array}$ & $\begin{array}{l}\text { Mean } \\
\text { Median } \\
\text { SD } \\
n\end{array}$ & $\begin{array}{c}1.41 \times 10^{5} \\
2.00 \times 10^{2} \\
9.96 \times 10^{5} \\
62\end{array}$ & $\begin{array}{c}4.30 \times 10^{3} \\
0 \\
1.24 \times 10^{4} \\
61\end{array}$ & $\begin{array}{c}5.7 \\
0.3 \\
12.2 \\
56\end{array}$ & $\begin{array}{l}2.7 \\
0.0 \\
6.2 \\
53\end{array}$ \\
\hline $\begin{array}{l}\text { Fall } \\
\text { (Sep-Oct) }\end{array}$ & $\begin{array}{l}\text { Mean } \\
\text { Median } \\
\mathrm{SD} \\
\mathrm{n}\end{array}$ & $\begin{array}{c}1.74 \times 10^{5} \\
3.84 \times 10^{4} \\
4.69 \times 10^{5} \\
29\end{array}$ & $\begin{array}{c}1.8 \times 10^{4} \\
2.01 \times 10^{3} \\
4.78 \times 10^{4} \\
29\end{array}$ & $\begin{array}{c}17.2 \\
10.2 \\
22.1 \\
29\end{array}$ & $\begin{array}{l}5.7 \\
2.0 \\
8.5 \\
29\end{array}$ \\
\hline $\begin{array}{l}\text { Winter } \\
\text { (Nov-Feb) }\end{array}$ & $\begin{array}{l}\text { Mean } \\
\text { Median } \\
\mathrm{SD} \\
\mathrm{n}\end{array}$ & $\begin{array}{c}1.25 \times 10^{4} \\
1.49 \times 10^{4} \\
1.06 \times 10^{4} \\
12\end{array}$ & $\begin{array}{c}2.19 \times 10^{4} \\
1.53 \times 10^{4} \\
2.39 \times 10^{4} \\
11\end{array}$ & $\begin{array}{l}2.1 \\
0.8 \\
2.3 \\
11\end{array}$ & $\begin{array}{l}2.4 \\
0.8 \\
3.2 \\
11\end{array}$ \\
\hline
\end{tabular}


Table 4. Pseudo-nitzschia spp. in the water column, sediment traps, and surficial sediments in 1990 and 1991. n: number of samples

\begin{tabular}{|c|c|c|c|c|c|c|}
\hline & & $\%$ Cells in chains 199 & $\%$ Abundance ${ }^{b}$ & Cells in chains ${ }^{a}$ & $\begin{array}{c}1991 \\
\text { \% Live cells }\end{array}$ & $\%$ Abundance \\
\hline $\begin{array}{l}\text { Water } \\
\text { column }\end{array}$ & $\begin{array}{l}\text { Mean } \\
\text { Median } \\
\text { SD } \\
n\end{array}$ & & $\begin{array}{l}10.8 \\
1.9 \\
20.34 \\
85\end{array}$ & & & $\begin{array}{l}14 \\
2 \\
25.8 \\
45\end{array}$ \\
\hline Traps & $\begin{array}{l}\text { Mean } \\
\text { Median } \\
\text { SD } \\
n\end{array}$ & $\begin{array}{c}23 \\
3 \\
35.4 \\
32\end{array}$ & $\begin{array}{l}24 \\
10 \\
25.4 \\
34\end{array}$ & $\begin{array}{l}26 \\
15 \\
28.4 \\
27\end{array}$ & $\begin{array}{l}9.7 \\
8.2 \\
8.76 \\
30\end{array}$ & $\begin{array}{l}25 \\
14 \\
27.5 \\
25\end{array}$ \\
\hline $\begin{array}{l}\text { Surficial } \\
\text { sediment }\end{array}$ & $\begin{array}{l}\text { Mean } \\
\text { Median } \\
\text { SD } \\
n\end{array}$ & $\begin{array}{c}13 \\
1 \\
21.6 \\
7\end{array}$ & $\begin{array}{c}17 \\
6 \\
20.8 \\
8\end{array}$ & $\begin{array}{c}14 \\
0 \\
21.9 \\
11\end{array}$ & $\begin{array}{c}15 \\
0 \\
33.5 \\
11\end{array}$ & $\begin{array}{l}4.8 \\
3.2 \\
5.64 \\
13\end{array}$ \\
\hline
\end{tabular}
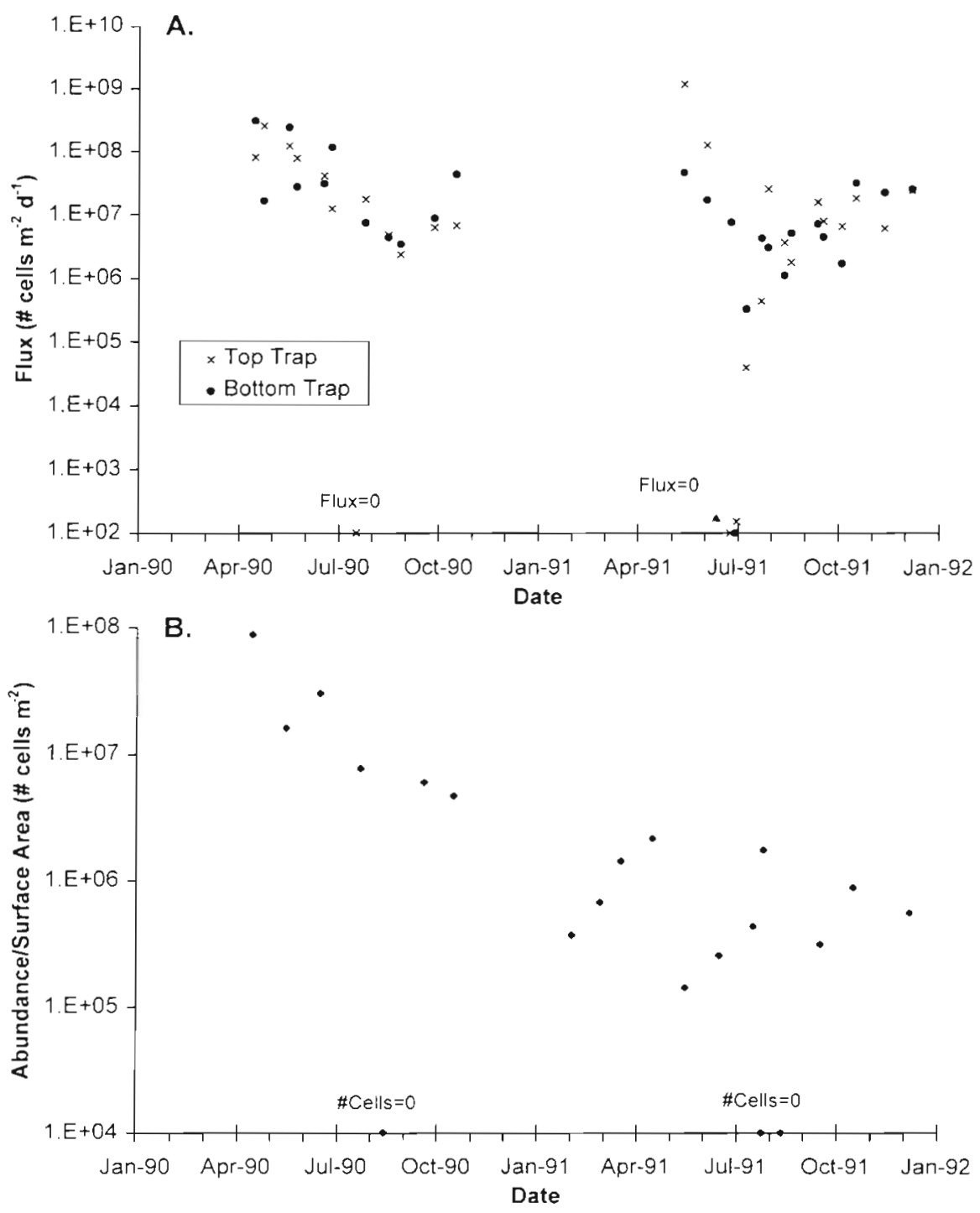

Fig. 4. Pseudo-nitzschia spp. Time series from 1990 to 1991 of (A) flux into sediment traps and (B) abundance in surficial sediments at the mooring site. Flux or abundance equal to zero indicated at appropriate date 
trap material were not in their characteristic chains in either 1990 or 1991 (Table 4), but occurred as single cells, which were difficult to identify, so that these counts may underestimate the vertical flux of Pseudonitzschia spp. There was a significant and linear relationship between the \% living cells and the \% cells in chains in 1991, suggesting that the chain structure is lost when the cells die.

The maximum flux was observed in the spring and fall in both 1990 and 1991 (Fig. 4A), indicating a seasonal pattern quite similar to that of Pseudo-nitzschia spp. abundance in the water (Fig. 3). Consequently, there is a significant, linear relationship between Pseudo-nitzschia spp. flux and Pseudo-nitzschia spp. concentration in the appropriate water layer $\left(\mathrm{r}^{2}=0.75\right.$, $\mathrm{n}=56$ ). In contrast, there was no apparent seasonal cycle in the concentration of Pseudo-nitzschia spp. cells in surficial sediments (Fig. 4B). The apparent lack of a seasonal cycle in abundance in the top $2 \mathrm{~mm}$ of sediment may result because the time period of accumulation is unknown and probably variable, due to variable sediment accumulation rates.

\section{Temporal and spatial variation in the Terrebonne Bay estuary}

Unlike the shelf, a seasonal cycle in Pseudo-nitzschia abundance was not apparent in the Terrebonne Bay estuary data (Fig. 5A). This environment is extraordinarily variable, as indicated by the large changes in salinity over short time periods (Fig. 5B), due primarily to changes in wind forcing and runof $f$ rather than tides (Reed 1995). Although the 3 stations were located close together, the \% frequency of occurrence of Pseudonitzschia spp. in all samples decreased from $23.4 \%$ at Stn 3 , nearest to Terrebonne Bay, to $12.5 \%$ at Stn 1 , further inland.

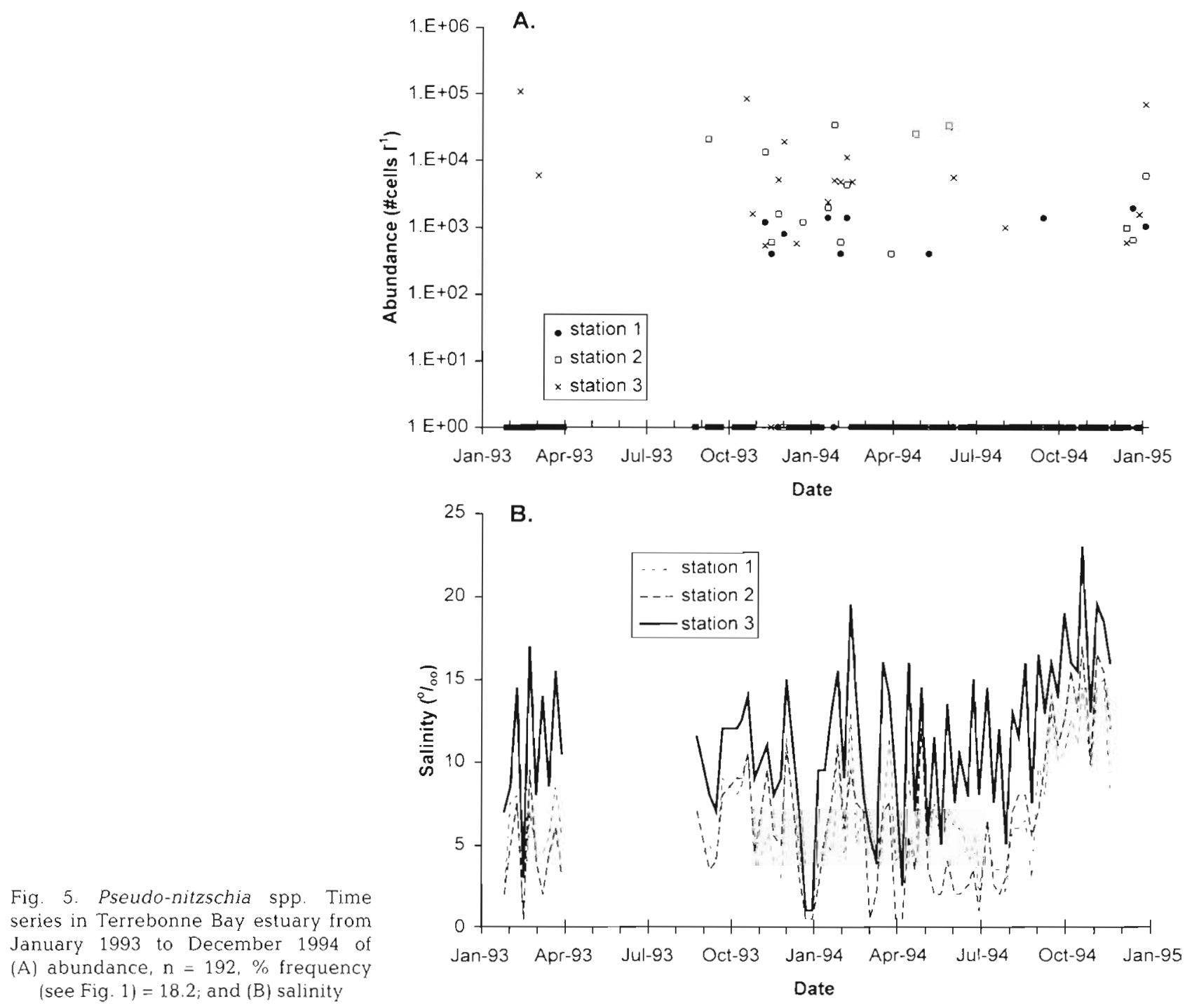




\section{Relationship of Pseudo-nitzschia abundance with environmental factors}

Pseudo-nitzschia spp. were found in high numbers over the entire salinity range (Fig. 6A). Although the highest numbers tended to occur at intermediate salinities and the lowest numbers at low salinities, this genus appeared to be extremely halotolerant. Similarly, Pseudo-nitzschia spp. are found over the full range of temperatures observed in this region (Fig. 6B).

Because Pseudo-nitzschia spp. abundance was not normally distributed and often could not be transformed to fit a normal distribution (see 'Methods: Statistics'), 2 approaches were taken to examine the relationship between Pseudo-nitzschia spp. abundance and environmental conditions (Table 5); only data from the well-mixed estuary and the upper water layer $(0$ to $1 \mathrm{~m}$ ) on the shelf were considered: (1) The environ- mental data for the upper water layer were separated into 2 groups, defined by the presence or absence of Pseudo-nitzschia spp. cells. Unlike Pseudo-nitzschia abundance, the environmental data either were normally distributed or could be transformed to fit a normal distribution. Student's $t$-test was used to compare the means of environmental data between the 2 groups (Table 5). (2) Using the same data, 2 non-parametric methods of calculating correlation coefficients were used to examine the relationship between Pseudonitzschia spp. abundance and various environmental variables: Spearman's rank correlation coefficient and Kendall's tau, based on concordance. Almost identical results were obtained for the 2 correlation coefficients, so that only the Spearman's rank correlation coefficients are reported (Table 5)

According to both approaches Pseudo-nitzschia spp. abundance is negatively related to $\Delta \sigma_{1}$ (difference in
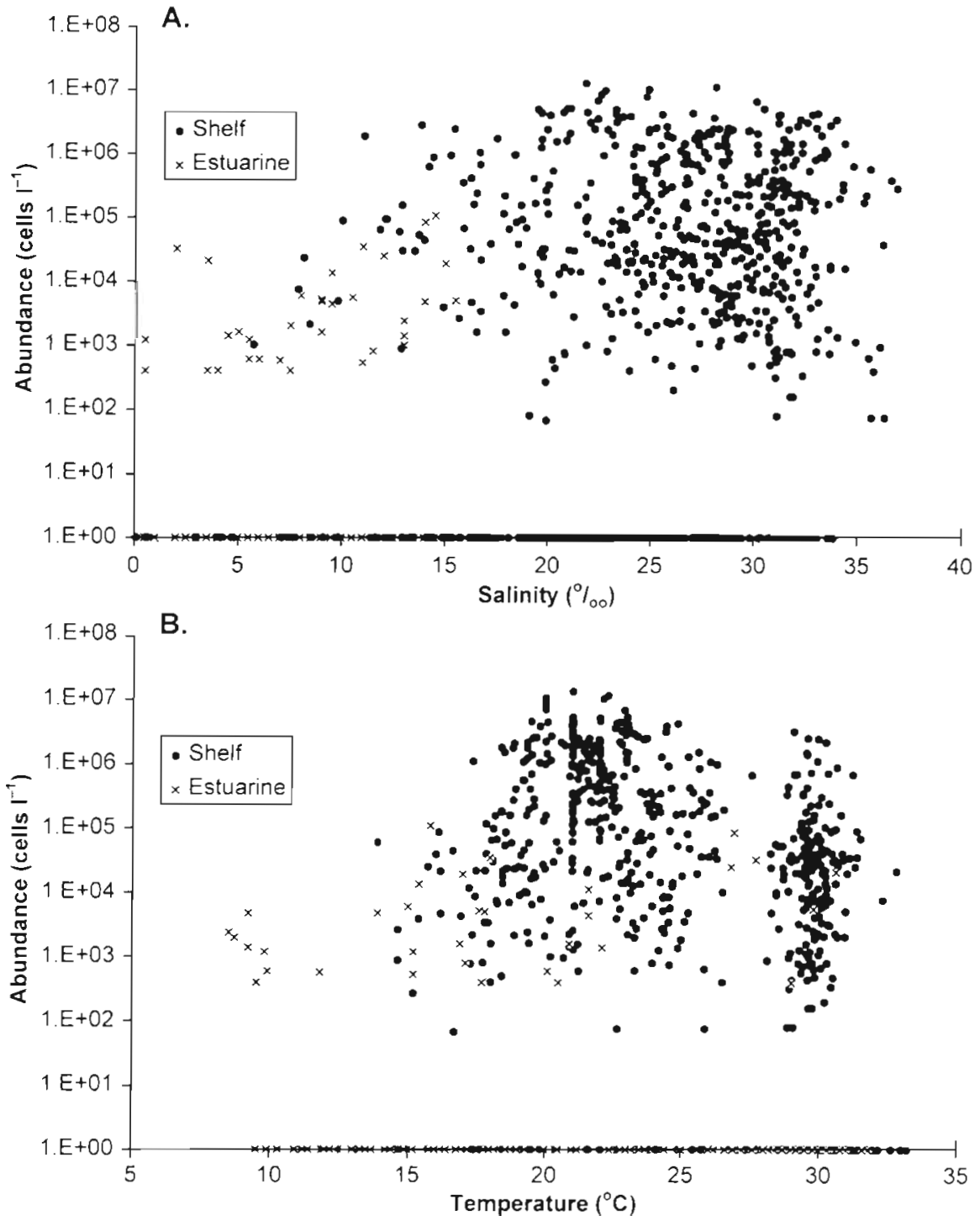

Fig. 6. Pseudo-nitzschia spp. abundance in the surface layer of shelf waters and in Terrebonne Bay estuary as a function of (A) salinity, $n=$ 1025 , \% frequency (see Fig. 1) = 59.7; and (B) temperature, $\mathrm{n}=856$, $\%$ frequency $=59.5$ 
Table 5. Mean environmental conditions \pm standard deviation (number of samples) when Pseudo-nitzschia spp. are present or absent and Spearman's rank correlation coefficient for Pseudo-nitzschia spp. abundance and environmental variables $(\mathrm{n}=\mathrm{sum}$ of the $2 \mathrm{n}$ numbers for presence/absence analysis). Includes all estuarine data and shelf data from 0 to $1 \mathrm{~m}$ depth. $\mathrm{n}$ varies because data are not available for all variables for all samples. "Means are significantly different (Student's $t$-test, non-normal data transformed d.b,c,d to test significance; means and standard deviations are presented using untransformed data); “-Spearman's rank correlation coefficients are significant

\begin{tabular}{|c|c|c|c|c|}
\hline & \multirow{2}{*}{ Variable } & \multicolumn{2}{|c|}{ Pseudo-nitzschia spp. } & \multirow{2}{*}{$\begin{array}{c}\text { Spearman correlation } \\
\text { Coefficients }\end{array}$} \\
\hline & & Absent & Present & \\
\hline \multirow[t]{3}{*}{ Hydrography } & Salinity $(\%)$ & $15.7 \pm 9.27(397)$ & $\cdot \quad 24.07 \pm 7.457(552)$ & $0.4110^{\cdots}$ \\
\hline & Temperature $\left({ }^{\circ} \mathrm{C}\right)$ & $26.0 \pm 6.01(340)$ & $\cdot \quad 24.41 \pm 4.886(462)$ & $-0.2273^{\cdots}$ \\
\hline & $\Delta \sigma_{\mathrm{t}}$ & $9.7 \pm 5.40(156)$ & $\cdot \quad 6.10 \pm 4.942(285)$ & $-0.2714^{\cdots}$ \\
\hline \multirow[t]{3}{*}{ Turbidity and light } & Transmittance $(\%)^{\mathrm{a}}$ & $82.6 \pm 10.17(122)$ & $79.3 \pm 15.94(226)$ & $-0.1322 \cdots$ \\
\hline & Secchi disk depth $(m)^{b}$ & $3.8 \pm 3.49(62)$ & $3.44 \pm 3.004(148)$ & -0.0903 \\
\hline & $\begin{array}{l}\text { Suspended particulate } \\
\text { matter }\left(\mathrm{mg} \mathrm{l}^{-1}\right)^{c}\end{array}$ & $13 \pm 18.9(39)$ & $10.1 \pm 8.90(81)$ & -0.1542 \\
\hline \multirow[t]{2}{*}{ Location } & Longitude & $90.72 \pm 0.952(411)$ & $\cdot \quad 91.27 \pm 1.689(578)$ & -0.0229 \\
\hline & Latitude & $29.059 \pm 0.2294(411)$ & - $28.973 \pm 0.3078(578)$ & $-0.2145 \cdots$ \\
\hline \multirow[t]{4}{*}{ Nutrients } & Phosphate $(\mu M)^{d}$ & $0.59 \pm 0.794(218)$ & $\cdot \quad 0.361 \pm 0.4661(4.37)$ & $-0.1385 \cdots$ \\
\hline & Silicate $(\mu \mathrm{M})^{d}$ & $16.4 \pm 26.37(221)$ & $7.0 \pm 10.35(442)$ & $-0.2792 \cdots$ \\
\hline & $\operatorname{DIN}(\mu M)^{d, e}$ & $16.1 \pm 24.47(210)$ & $8.5 \pm 11.74(4.13)$ & $-0.1593 \cdot \cdot$ \\
\hline & Si/DIN (by moles) ${ }^{\mathrm{d}}$ & $2.11 \pm 3.234(209)$ & $2.13 \pm 3.645(412)$ & $-0.1792 \cdot \cdot$ \\
\hline \multirow[t]{4}{*}{ Algal biomass } & Chlorophyll a $\left(\mu \mathrm{g} \mathrm{I}^{-1}\right)^{d}$ & $8.3 \pm 9.98(409)$ & $7.3 \pm 9.47(577)$ & 0.05612 \\
\hline & Total autotrophs & $\begin{array}{l}8.3 \times 10^{8} \\
+1078 \times 10^{8} 402\end{array}$ & $\begin{array}{r}2.19 \times 10^{8} \\
+3658 \times 10^{8}+568 t\end{array}$ & $-0.4160^{\circ}$ \\
\hline & Diatoms & $\begin{array}{r}3.5 \times 10^{6} \\
+733 \times 10^{6}(402)\end{array}$ & $3.52 \times 10^{6}$ & $0.2354^{\cdots}$ \\
\hline & $\left(\text { cells l }{ }^{-1}\right)^{d}$ & $\pm 7.33 \times 10^{6}(402)$ & $\pm 6.057 \times 10^{6}(568)$ & \\
\hline \multirow{2}{*}{\multicolumn{2}{|c|}{$\begin{array}{l}{ }^{d} t \text {-test performed on transformed data }\left(T=x^{3}\right) \\
{ }^{b} t \text {-test performed on transformed data }\left(T=x^{0.5}\right) \\
{ }^{t} \text {-test performed on transformed data }\left(T=x^{0.33}\right)\end{array}$}} & \multicolumn{3}{|c|}{${ }^{d} t$-test performed on transformed data $(T=\log (x+0.1)$} \\
\hline & & \multicolumn{3}{|c|}{${ }^{e} \mathrm{DIN}=$ nitrate + nitrite + ammonium } \\
\hline
\end{tabular}

$\sigma_{t}$ from surface to bottom), which is an approximation of the water column stability. The observed positive relationship with salinity and negative relationship with temperature (Table 5) would be expected if decreased stability was a major factor determining abundance. Based on comparisons of latitude and longitude where Pseudo-nitzschia spp. were observed, they are more likely to occur in the western portion of the sampling area and somewhat offshore. Pseudonitzschia spp. abundance was significantly and negatively related to all nutrient concentrations, including nitrate and ammonium, separately, which are not shown. In general there were no differences in the measures of turbidity (transmittance and SPM) or light (Secchi disk depth) when Pseudo-nitzschia spp. were present or absent, but there was less data available for these analyses. Finally, abundance of total autrotophs was negatively related to abundance of Pseudonitzschia spp., because small cyanobacteria are especially abundant in summer (Dortch 1994), when Pseudo-nitzschia spp. are not as likely to occur. For other variables, the 2 approaches gave different results.

\section{DISCUSSION}

\section{Presence of Pseudo-nitzschia spp. in the northern Gulf of Mexico}

Pseudo-nitzschia spp. are an abundant and often dominant diatom genus in Louisiana/Texas shelf waters. Maximum concentrations far exceed those reported for any other area (Villac et al. 1993b). Their concentrations in the Terrebonne Bay estuary are considerably lower than in shelf waters; although often present, Pseudo-nitzschia spp. also do not dominate the diatom flora as they do on the shelf. Similar results were obtained in Galveston Bay, Texas (Fryxell et al. 1990)

At present 3 species have been identified in this region: Pseudo-nitzschia multiseries (Fryxell et al. 1990), which is usually considered toxic, $P$. pungens (Fryxell et al. 1990), which is considered non-toxic, and $P$. pseudodelicatissima (this study), which is sometimes toxic (Martin et al. 1990). Fryxell et al. (1990, 1991) have hypothesized that there may be a suite of $P$ seudonitzschia spp. present in this area with differing growth 
requirements and toxicities. In particular temperature appears to be a major factor determining species composition (Fryxell et al. 1990, Villac et al. 1993b, Hasle \& Syvertsen 1996).

\section{Role of environmental factors}

On the shelf there is a clear seasonal cycle in both Pseudo-nitzschia spp. abundance and vertical flux, with a large peak in the spring and a smaller peak in the fall. The spring peak corresponds with the average maximum in river flow (Boyles \& Humphries 1994). However, during the study period river flow peaked as early as January or as late as June and was often characterized by a series of maxima. Moreover, the fall bloom of Pseudo-nitzschia spp. always occurred during a period of low flow. Thus, riverine inputs alone cannot expldin the seasonal cycle of Pseudo-nitzschia spp.

Another characteristic of the spring and fall periods is the passage of frontal systems and storms which, at least for a short time, break down the stratification, as indicated by data obtained from the instrument array on the mooring (Rabalais et al. 1992, 1994, Wiseman et al. 1992). Since Pseudo-nitzschia spp. are present when stability is lower (Table 5), mixing events may be an important mechanism in resupplying nutrients to the surface layer. Despite high nutrient inputs from the river, high nutrient concentrations are usually only observed near the river mouth, nutrient concentrations over the rest of the shelf can be quite low, and regenerated nutrients are surprisingly important (Turner \& Rabalais 1991, Dortch \& Whitledge 1992, Cotner \& Gardner 1993, Bode \& Dortch 1996). In the spring, the passage of fronts results in upwelling and corresponding increases in surface nutrients and chlorophyll (Dagg 1988). In the fall, mixing events would advect nutrient rich water from the hypoxic zone below the pycnocline (N. N. Rabalais, R. E. Turner \& W J. Wiseman Jr unpubl. data) up into the nutrient-depleted surface layer. Elsewhere, indirect evidence indicates that nutrient inputs stimulated the development of blooms of Pseudo-nitzschia spp. (Buck et al. 1992, Smith et al. 1993, Lange et al. 1994).

While the timing of Pseudo-nitzschia spp. blooms in the Louisiana/Texas coastal zone suggests nutrient stimulation, the significant negative relationship between Pseudo-nitzschia spp. presence and all nutrient concentrations would appear to argue against it (Table 5). In the field, highest cell numbers are often associated with the lowest nutrient concentrations. Thus, it may be difficult to establish a relationship between abundance and nutrients, based only on nutrient concentrations, when the critical processes of species-specific nutrient uptake and growth cannot be measured. In mixed species cultures, $P$. multiseries (formerly P. pungens f. multiseries, Hasle 1995) tended to dominate under low light and at relatively low $\mathrm{Si} / \mathrm{N}$ ratios (Sommer 1994), and in single species cultures, it grew well with all $\mathrm{N}$ sources except ammonium (Hillebrand \& Sommer 1996).

The other difficulty is that a suite of species is being treated as a single entity. The very broad salinity and temperature ranges over which Pseudo-nitzschia spp. were observed suggest there is more than 1 species present. Autoecological studies with isolates from a variety of areas indicate that individual species/clones have much narrower temperature and salinity preferences (Fryxell et al. 1990, Reap 1991, Jackson et al. 1992, Hasle $\&$ Syvertsen 1996). It is likely that they will also have different nutrient requirements. Consequently, it will be necessary to identify the species present in all field samples in order to fully understand how environmental conditions affect the abundance of the Pscudo-nitzschia group and, thus, the potential for toxic events.

\section{Historical data and eutrophication}

Nitrogen and phosphorus inputs to the coastal zone from the Mississippi and Atchafalaya rivers have increased since the 1950s (Turner \& Rabalais 1991). This has led to increasing eutrophication in the coastal zone, as indicated by increased biogenic silica deposition in sediment cores (Turner \& Rabalais 1994, Rabalais et al. 1996). Eutrophication has also increased in several Louisiana estuaries (Rabalais et al. 1995, 1996, Parsons 1996). If there is a link between nutrient availability and Pseudo-nitzschia spp. abundance, then abundance should have increased both on the shelf and in estuaries, at least in proportion to diatorn abundance. Further, Si inputs have decreased substantially as $\mathrm{N}$ inputs have increased, decreasing the $\mathrm{Si} / \mathrm{N}$ ratio of riverine nutrient input by a factor of 4 (Turner \& Rabalais 1991). Since mixed species culture experiments indicate that $P$. multiseries (formerly Nitzschia pungens f. multiseries, Hasle 1995) dominates when Si/N ratios are low (Sommer 1994), the relative abundance of Pseudo-nitzschia spp. in comparison with total diatoms may have also increased.

Pseudo-nitzschia spp. have been observed in this area since the earliest studies in the 1950 s and have been identified as Nitzschia pungens, $N$. pungens var Atlantica, and $N$. seriata. They have been observed in estuaries, such as Barataria Bay, Louisiana (Day et al. 1973, Hart 1979), Bay St. Louis, Mississippi (Housely 1976), Lake Calcasieu, Louisiana (Maples et al. 1982, 1983, Fay \& Schnitzer 1984), and Galveston Bay, Texas (Fryxell et al. 1990) and on the northern Gulf of Mexico shelf (Simmons \& Thomas 1962, Housely 1974, Fucik \& 
El-Sayed 1979). Most of these earlier studies give insufficient data to determine whether the abundance of Pseudo-nitzschia spp. has increased over time. although individual Pseudo-nitzschia species are sometimes listed as abundant.

Two studies on the shelf provide some quantitive data for comparison with data collected in 1990-1994. In the period 1955 to 1957 , phytoplankton were identified in numerous samples from the Louisiana coastal zone off the Mississippi River delta (Simmons \& Thomas 1962). Abundances of Pseudo-nitzschia spp. were generally much lower than observed at present in similar places and times. For example, the maximum observed concentration of Pseudo-nitzschia spp. was $2 \times 10^{5}$ cells $1^{-1}$ at a salinity of $23.5 \%$ (Simmons \& Thomas 1962). Presently, at this salinity Pseudo-nitzschia spp. maximum concentrations exceed $10^{7}$ cells $\mathrm{l}^{-1}$ (Fig. 6A). While this suggests that Pseudo-nitzschia spp. abundance has increased since 1955-1957, differences are difficult to quantify because Simmons \& Thomas (1962) conducted their sampling to the east of the Mississippi River delta, whereas sampling in this study has focused primarily on the region to the west of the delta. Further, they did not sample during April when the peak in Pseudo-nitzschia spp. abundance was observed in 1990-1994. Fucik \& El-Sayed (1979) sampled phytoplankton on 12 cruises from January 1972 to January 1974 at 2 stations near the present mooring site. During that period, the relative abundance of Pseudonitzschia spp. to the total phytoplankton ranged from 0 to $17 \%$, with most of the values $<1 \%$. Most of the species reported by Fucik \& El-Sayed (1979) were diatoms, so their \% abundance based on total phytoplankton is equivalent to that based on diatoms presented here. In the present study, the \% abundance of Pseudo-nitzschia spp. at the mooring site relative to diatoms ranged from 0 to $100 \%$ and averaged $10 \%$. Consequently, the published historical data, especially those of Fucik \& El-Sayed (1979), support the hypothesis that Pseudo-nitzschia spp. have become more abundant. At the same time nutrient input and eutrophication have increased substantially (Turner \& Rabalais 1991, 1994, Rabalais et al. 1996). The hypothesis that the increase in Pseudo-nitzschia abundance was related to increasing eutrophication requires rigorous testing, but is important because of the growing suspicion that harmful algal blooms are increasing worldwide as a result of coastal eutrophication (Anonymous 1995).

\section{Flux of Pseudo-nitzschia spp.}

The vertical flux of Pseudo-nitzschia spp. was extremely high. Maximum rates exceeded those in traps in Monterey Bay, California, by more than an order of magnitude, although the \% abundance was not as great (Buck et al. 1992). To put these fluxes in perspective, the abundance of Pseudo-nitzschia spp. can be integrated over depth at the mooring site for the upper and lower water layers and the daily flux over a specific period can be compared with the average integrated abundance for the same time period. On average $46 \%$ of the Pseudo-nitzschia present in a particular water layer sank into that trap each day. However, the variability was high and the \% trapped sometimes exceeded what was available in the overlying water column. This could be an axtifact of the sampling because the data on concentrations in the water were usually only available for the days the traps were put in and taken out and undetected blooms could have occurred during the interim period. It could also be due to the horizontal advection of cells or by over-collection in the traps. Surficial sediments also contained substantial numbers of Pseudo-nitzschia. Because of the difficulty calculating short-term sedimentation rates, it is not possible to calculate a daily loss rate to the sediment.

Most of the sinking Pseudo-nitzschia did not occur in chains in either the traps or surficial sediments. Further, in 1991 there was a correlation between the \% of cells in chains and the \% of cells which were alive. This is consistent with the observations from clonal cultures isolated from the northern Gulf of Mexico that when cells ceased growing, the chains disassociated into single cells or doublets, sank to the bottom, and lost their color (Fryxell et al. 1990).

\section{Threat posed by Pseudo-nitzschia spp. in the northern Gulf of Mexico}

The exact distribution of toxic and non-toxic species has not been determined, but at least 2 potentially toxic species have been observed in the northern Gulf of Mexico. Toxic and non-toxic clones of Pseudonitzschia multiseries (formerly Nitzschia pungens f. multiseries) were isolated from Galveston Bay (Fryxell et al. 1990). Toxic clones were more likely to be isolated during cool months (Fryxell et al. 1990) and their growth requirements suggest they prefer lower temperatures (Reap 1991). A bloom of P. pseudodelicatissima was identified by SEM at the mooring site in May 1993. This species has been identified as the source of domoic acid in the Bay of Fundy, Canada (Martin et al. 1990).

It is critical to determine the species present on the shelf and their toxin production because of the extremely high numbers which are frequently encountered, especially in the spring. Moreover, environmental conditions may enhance toxin production if 
toxin-producing species are present. Despite high nutrient inputs, the surface waters become severely Sidepleted in the spring in comparison with summer (Dortch \& Whitledge 1992, Dortch et al. 1995, Smith \& Hitchcock 1994, Nelson \& Dortch 1996). Further, dissolved silicate/inorganic nitrogen ratios tend to be quite low in the upper water layer, indicating an excess of nitrogen. Such conditions in cultures enhance domoic acid production (Bates et al. 1991, Bates \& Douglas 1993, Pan et al. 1996a, b). As a result, domoic acid production could be at its highest level when cell abundance is maximal.

Domoic acid could enter both pelagic and benthic food chains on the shelf. The direct sinking into traps and surficial sediments makes the material available to an array of benthic organisms. Taylor (1993) hypothesized that Dungeness and rock crabs on the west coast of the USA and Canada became toxic by consuming, either directly or indirectly, a Pseudo-nitzschia bloom that sank to the bottom. Along the Gulf coast, shrimp and demersal fish, such as drum, are the commercially harvested species that might acquire toxin from sinking Pseudo-nitzschia. The most likely pelagic grazers are large copepods, such as Eucalanus, which are major consumers of phytoplankton (Dagg 1995), and menhaden, which are extremely abundant (Deegan \& Thompson 1985) and fill the niche equivalent to anchovies on the west coast (E. M. Chesney pers. comm.). Because both are consumed by a variety of other organisms, the toxin could become widely distributed and ultimately affect humans and other consumers.

The maximum Pseudo-nitzschia spp. abundance in the estuary was $10^{5}$ cells $\mathrm{l}^{-1}$. Although these abundances are much less than on the shelf, they are as high or higher than Pseudo-nitzschia spp. abundances that led to toxicity in blue mussels (Hanic 1989, cited in Dickey et al. 1992) and anchovies/seabirds (Garrison \& Walz 1993). Further, these samples were taken $0.3 \mathrm{~m}$ above oyster beds in a region with a substantial oyster industry (Dugas et al. 1982). Oysters accumulate toxin, although perhaps not to the high levels observed in blue mussels (Roelke 1993). Identification of the species of Pseudo-nitzschia and measurement of domoic acid in phytoplankton, oysters, and other higher trophic levels are essential in assessing the potential risk.

Acknowledgements. This research was funded by: NOAA Coastal Ocean Program Office, Nutrient Enhanced Coastal Ocean Productivity (NECOP) grant no. NA90AA-D-SG691 to the Louisiana Sea Grant College Program (award nos. MAR02 and MAR92-02 to Q.D. and nos. MAR31A and MAR92-07A to N.N.R., D. E. Harper Jr, and R. E. Turner); Department of Interior Minerals Management Service Mississippi River Plume Hydrographic Study (LATEX B), contract no. 14-35-000130632 to Louisiana State University (subcontract no. R158977 to N.N.R. and Q.D. at LUMCON); NOAA National Undersea
Research Center grant no. 90-91-GM-SCU/ROV to N.N.R et al.; Louisiana Board of Regents grant nos. LASER 86-LUM(1)083-13 to M. Dagg and LEQSF (1987-1990)-RD-A-15 to N.N.R.; and Nicholls State University Research Council grant no. 02-22 to T.M.S. We thank the captains and crews of the RV 'Pelican', RV 'Acadiana', and RV 'Malcolm Baldridge' and the many research assistants and volunteers for collections of samples. We especially thank Ben Cole and Lorene Smith for field and laboratory assistance and data management and Deidre Gibson for help in manuscript preparation. We also appreciate critical reading of an early manuscript by $\mathrm{Dr} G$. J. Doucette and the helpful comments of 2 unknown reviewers.

\section{LITERATURE CITED}

Anonymous (1995) ECOHAB: the ecology and oceanography of harmful algal blooms, a national research agenda. Biol Dept, Woods Hole Oceanographic Institution, Woods Hole, MA

Bates SS, Bird CJ, de Freitas ASW, Foxal R, Gilgan M, Hanic LA, Johnson GR, McCulloch AW, Idense P, Pocklington R, Quilliam MA, Sim PG, Smith JC, Subba Rao DV, Todd ECD, Walker JA, Wright JLC (1989) Pennate diatom Nitzschia pungens as the primary source of domoic acid, a toxin in shellfish from eastern Prunce Edward Island, Canada. Can J Fish Aquat Sci 46:1203-1215

Bates SS, de Freitas ASW, Milley JE, Pocklington R, Quilliam MA, Smith JC, Worms J (1991) Controls on domoic acid production by the diatom Nitzschia pungens f. multiseries in culture: nutrients and irradiance. Can J Fish Aquat Sci 48:1136-1144

Bates SS, Douglas DJ (1993) Laboratory studies of domoic acid production by Pseudonitzschia pungens. Harmful Algae News 6:6-7

Bode A, Dortch Q (1996) Uptake and regeneration of inorganic nitrogen in coastal waters influenced by the Mississippi River: spatial and seasonal variations. J Plankton Res (in press)

Boyles R Jr, Humphries Q (1994) Lower Mississıppi Rıver streamflow. In: Dowgiallo MJ (ed) Coastal oceanographic effects of 1993 Mississippi River flooding. NOAA Coastal Ocean Office/Natıonal Weather Service, Silver Spring, MD, p 28-29

Buck KR, Uttal-Cooke L, Pilskaln CH, Roelke DL, Villac MC, Fryxell GA, Cifuentes L, Chavez FP (1992) Autecology of the diatom Pseudonitzschia australis, a domoic acid producer, from Monterey Bay, California. Mar Ecol Prog Ser $84: 193-302$

Cotner JB Jr, Gardner WS (1993) Heterotrophic bacterial mediation of ammonium and dissolved free amino acid fluxes in the Mississippi River plume. Mar Ecol Prog Ser 93:75-87

Dagg MJ (1988) Physical and biological responses to the passage of a winter storm in the coastal and inter shelf waters of the northern Gulf of Mexico. Cont Shelf Res 8:167-178

Dagg MJ (1995) Copepod grazing and the fate of phytoplankton in the northern Gulf of Mexico. Cont Shelf Res 15 1303-1317

Day JW Jr, Smith WG, Wagner PR, Stowe WC (1973) Community structure and carbon budget of a salt marsh and shallow bay estuarine system in Louisiana. Louisıana Sea Grant Publication 72-04, Baton Rouge

Deegan LA, Thompson BA (1985) The ecology of fish communities in the Mississippi River deltaic plain. In: YanezArancibia A (ed) Fish community ecology in estuaries and coastal lagoons, towards an ecosystem integration. 
UNAM-ICML Publishers, Mexico City, p 35-36

Dickey RW, Fryxell GA, Granade HR, Roelke D (1992) Detection of the marine toxins okadaic acid and domoic acid in shellfish and phytoplankton in the Gulf of Mexico. Toxicon 30:355-359

Dortch Q (1994) Changes in phytoplankton numbers and species composition. In: Dowgiallo MJ (ed) Coastal oceanographic effects of 1993 Mississippi River flooding. NOAA Coastal Ocean Office/National Weather Service, Silver Spring, MD, p 46-49

Dortch Q, Milsted D, Rabalass NN, Lohrenz SE, Redalje DG, Dagg MJ, Turner RE, Whitledge TE (1992) Role of silicate availability in phytoplankton species composition and the fate of carbon. Texas Sea Grant Tech Rep 92-109, Galveston, $\mathrm{p} 76-83$

Dortch Q, Nelson DM, Turner RE, Rabalass NN (1995) Silicate limitation on the Louisiana contunental shelf. Proc NOAA Nutrient Enhanced Coastal Ocean Productivity 1994 Synthesis Workshop, Louisiana Sea Grant Technical Report, Baton Rouge, p 34-39

Dortch Q, Whitledge TE (1992) Does nitrogen or silicon limit phytoplankton production in the Mississippi River plume and nearby regions? Cont Shelf Res 12:1293-1309

Drum AS, Siebens TL, Crecelius EA, Elston RA (1993) Domoic acid in the Pacific razor clam Siliqua patula (Dixon, 1789). J Shellfish Res 12:443-450

Dugas RJ, Pausina RV, Voison M (1982) The Louisiana oyster industry, 1980. In: Chew KK (ed) Proceedings of the North American Oyster Workshop, Louisiana State University Division of Continuing Education, p 101-111

Fay R, Schnitzer M (1984) Phytoplankton. In: Hann RW Jr, Giamona CP, Randall RE (eds) Offshore oceanographic and environmental monitoring services for the strategic petroleum reserve: eighteen-month report for the $W$ Hackberry Site from May 1982 through Nov 1983. Dept of Energy: NTIS, DOE-PO10850-3, Springfield, VA, p 7-1-7-51

Fritz L, Quilliam MA, Wright JLC, Beale AM, Work TM (1992) An outbreak of domoic acid poisoning attributed to the pennate diatom Pseudonitzschia australis. J Phycol 28: $439-442$

Fryxell GA, Reap ME, Roelke DL, Cifuentes LA, Valencic DL (1991) Confurmed presence of neurotoxin-producing diatoms around Galveston, Texas. In: Shipley FS, Diesling RW (eds) Proceedings Galveston Bay Characterization Workshop, Publication GBNEP-6. Galveston Bay National Estuary Program, Galveston, p 153-154

Fryxell GA, Reap ME, Valencic DL (1990) Nitzschia pungens Grunow f. multisenes Hasle: observations of a known neurotoxic diatom. Nova Hedwigla 100:171-188

Fucık KW, El-Sayed SZ (1979) Effect of oil production and drilling operations on the ecology of phytoplankton in the OEl study area. In: Ward CH, Bender ME, Reish DJ (eds) The offshore ecology investigation, effects of oil drillıng and production in a coastal environment. Rice University Studies 65:325-353

Garrison D, Walz P (1993) North Pacific coast of USA: toxic diatom blooms and domorc acid. Harmful Algae News 6:5

Hanic L (1989) Aquaculture: nutrition, health and technology. Technical University of Nova Scotia

Hart DL (1979) The relationship of phytoplankton to petroleum recovery activities in a Louisiana salt marsh. MS thesis, Louisiana State University, Baton Rouge

Hasle GR, Syvertsen EE (1996) Marine diatoms. In: Tomas CR (ed) Identıfying marine dratoms and dinoflagellates. Academic Press, San Diego, p 5-385

Hendee JC (1994) Data management for the Nutrient Enhanced Coastal Ocean Productivity Program. Estuanes 17.
$900-903$

Hillebrand H, Sommer U (1996) Nitrogenous nutrition of the potentially toxic diatom Pseudonitzschia pungens f. multiseries Hasle. J Plankton Res 18:295-301

Hitchcock G. Whitledge TE (1992) Nutrient/pigment variability in the Mississippi River plume and adjacent waters. Texas Sea Grant Tech Rep 92-109, Galveston, TX, p 43-51

Horner RA, Kusske MB, Moynihan BP, Skinner RN, Wekell JC (1993) Retention of domoic acid by Pacific razor clams, Siliqua patula (Dixon, 1789): preliminary study. J Shellfish Res 12:451-456

Horner RA, Postel JR (1993) Toxic diatoms in western Washington waters (US west coast). Hydrobiologia 269/270: $197-205$

Housley HL (1976) Distribution, periodicity, and identification of the phytoplankton in the Bay of St Louis, MS, and the northeastern Gulf of Mexico. PhD dissertation, University of Mississippi

Jackson AR, Ayer SW, Laycock MV (1992) The effects of salinity on growth and amino acid composition in the marine diatom Nitzschia pungens. Can J Bot 70:2198-2201

Lange CB, Reid FMH, Vernet M (1994) Temporal distribution of the potentially toxic diatom Pseudonitzschia australis at a coastal site in southern California. Mar Ecol Prog Ser 104:309-312

Langlois GW, Kizer KW, Hansgen KH, Howell R, Loscutoff SM (1993) A note on domolc acid in California coastal molluscs and crabs. J Shellfish Res 12:467-468

Lewis NI, Bates SS, McLachlan JL, Smıth JC (1993) Temperature effects on growth, domoic acid production, and morphology of the diatom Nitzschia pungens f. multiseries. In: Smayda TJ, Shimizu Y (eds) Toxic phytoplankton blooms in the sea. Elsevier Science Publishers, Amsterdam, p $601-606$

Lundholm N, Skov J, Pocklington R, Moestrup O (1994) Domoic acad, the toxic amino acid responsible for amnesic shellfish poisoning, now in Pseudonitzschia seriata (Bacillariophyceae) in Europe. Phycologia 33:475-478

Maples R (1982) Phytoplankton. In: DeRouen LR, Hann RW, Casserly DM, Giammona C (eds) West Hackberry brine disposal project pre-discharge characterization final report. Dept of Energy: NTIS, DOE/PO-10288-1, Springfield, VA, p 7-1-7-59

Maples R (1983) Phytoplankton. In: DeRouen LR, Hann RW, Casserly DM, Giammona C, Lascara VJ (eds) West Hackberry strategic petroleum reserve site brine disposal monitoring, year I report. Dept of Energy: NTIS, DOE/PO10288-1, Springfield, VA, 3:8-1-8-78

Martin JL, Haya K. Burridge LE, Wildish DJ (1990) Nitzschia pseudodelicatissima-a source of domoic acid in the Bay of Fundy, eastern Canada. Mar Ecol Prog Ser 67:177-182

Murphy LS, Haugen EM (1985) The distribution and abundance of phototrophic ultraplankton in the North Atlantıc. Limnol Oceanogr 30:47-58

Nelson DM, Dortch Q (1996) Silıcic acıd depletion in the plume of the Missıssippi River and limitation of Si availability to diatoms in the northern Gulf of Mexico: evidence from kinetic studies in spring and summer. Mar Ecol Prog Ser 136:163-178

Pan Y, Subba Rao DV, Mann KH, Brown RG, Pocklington R (1996) Effects of silicate limitation on production of domoic acid, a neurotoxin, by the diatom Pseudo-nitzschia multiseries. 1. Batch culture studies. Mar Ecol Prog Ser 131: $225-233$

Pan Y, Subba Rao DV, Mann KH, Li WKW, Harrison WG (1996) Effects of silicate limitation on production of domoic acid, a neurotoxin, by the diatom Pseudo-nitzschia multi- 
series. II. Continuous culture studies. Mar Ecol Prog Ser 131:235-243

Parsons ML (1996) Paleoindicators of changing water conditions in Louisiana estuaries. PhD dissertation, Louisiana State University, Baton Rouge

Parsons TR, Maita Y, Lalli CM (1984) A manual of chemical and biological methods for sewater analysis. Pergamon Press, Oxford

Prior DG, Bornhold BD, Wiseman WJ Jr, Lowe DR (1987) Turbidity current activity in a British Columbia fjord. Science $237: 1330-1333$

Qureshi NA (1995) The role of fecal pellets in the flux of carbon to the sea floor on a river-influenced continental shelf subject to hypoxia. PhD dissertation, Louisiana State University, Baton Rouge

Rabalais NN, Dortch Q, Justic' D, Kilgen MB, Klerks PL Templet $\mathrm{PH}$, Turner RE, Cole B, Duet D, Beacham $M_{\text {, }}$ Lentz S, Parsons M, Rabalais S, Robichaux R (1995) Status and trends of eutrophication, pathogen contamination, and toxic substances in the Barataria and Terrebonne estuarine system. BTNEP Publ No. 22, Barataria-Terrebonne National Estuary Program, Thibodaux, LA

Rabalais NN, Tumer RE, Justic' D, Dortch Q, Wiseman WJ Jr, Sen Gupta BK (1996) Nutrient changes in the Mississippi River and system responses on the adjacent continental shelf. Estuaries 19:386-407

Rabalais NN, Turner RE, Wiseman WJ Jr (1992) Distribution and characteristics of hypoxia on the Louisiana shelf in 1990 and 1991. Texas Sea Grant Tech Rep 92-109, Galveston, p 15-20

Rabalais NN, Turner RE, Wiseman WJ Jr, Boesch DF (1991) A brief summary of hypoxia on the northern Gulf of Mexico continental shelf: 1985-1988. In: Tyson RV, Pearson TH (eds) Modern and ancient continental shelf anoxia. Geological Society Spec Publ No. 58:35-47

Rabalais NN, Wiseman WJ Jr, Tumer RE (1994) Comparison of continuous records of near-bottom oxygen from the hypoxic zone of Lousiana. Estuaries 17:850-861

Reap ME (1991) Nitzschia pungens Grunow f. multiseries Hasle: growth phase and toxicity of clonal cultures isolated from Galveston, TX. MS thesis, Texas A\&M University, College Station

Reed DJ (1995) Current status and historical trends of hydrologic modification, reduction in sediment availability and habitat loss/modification. BTNEP Publ No. XX, BaratariaTerrebonne National Estuary Program, Thibodaux, LA

Roelke DL (1993) Feeding experiments of Crassostrea virginica on two forms of Pseudonitzschia pungens: behavior and toxicity. MS thesis, Texas A\&M University, College Station

Shapiro SP, Haugen EM, Carpenter EJ (1989) Occurrence and abundance of green-fluorescing dinoflagellates in the surface waters of the northwest Atlantic and northeast Pacific oceans. J Phycol 25:189-191

Simmons EG. Thomas WH (1962) Phytoplankton of the eastern Mississippi delta. Publ Inst Mar Sci, University of Texas 8:269-298

Smith JC, McLachlan JL, Cormier PG, Pauley KE, Bouchard
$N$ (1993) Growth and domoic acid production and retention by Nitzschia pungens f. multiseries at low temperatures. In: Smayda TJ, Shimizu Y (eds) Toxic phytoplankton blooms in the sea. Elsevier Science Publishers, Amsterdam, p 631-636

Smith SM, Hitchcock GL (1994) Nutrient enrichments and phytoplankton growth in the surface waters of the Louisiana Bight. Estuaries 17:740-753

Sokal RR, Rohlf FJ (1969) Biometry, the principles and practice of statistics in biological research. WH Freeman \& Co, San Francisco

Sommer U (1994) Are marine diatoms favoured by high Si:N ratios? Limnol Oceanogr 115:309-315

Taylor FJR (1993) British Columbia: implications of the North American west coast experience. Harmful Algae News 6: $2-3$

Todd ECD (1993) Domoic acid and amnesic shellfish poisoning-a review. J Food Prot 56:69-83

Toon R, Dagg M (1991) LaSER Oceanography: data report number 6 CTD and hydrographic data, R/V Pelican cruise, October 23-29, 1990. Louisiana Universities Marine Consortium Data Rep 13, Cocodrie

Toon R, Dagg M (1992a) Nutrient enhanced coastal ocean productivity data report: CTD and hydrographic data, R/V Pelican cruise, September 12-18, 1991. Louisiana Universities Marine Consortium Data Rep 14, Cocodrie

Toon R, Dagg M (1992b) Nutrient enhanced coastal ocean productivity data report: CTD and hydrographic data, R/V Pelican cruise, May 5-7, 1992. Louisiana Universities Marine Consortium Data Rep 16, Cocodrie

Toon R, Dagg $M$ (1993) Nutrient enhanced coastal ocean productivity data report: CTD and hydrographic data, R/V Pelican cruise, April 3-11, 1993. Louisiana Universities Marine Consortium Data Rep 20, Cocodrie

Turner RE, Rabalais NN (1991) Changes in Mississippi River water quality this century. BioSci 41:140-147

Turner RE, Rabalais NN (1994) Coastal eutrophication near the Mississippi river delta. Nature 368:619-621

Villac MC, Roelke DL, Chavez FP, Cifuentes LA, Fryxell GA (1993a) Pseudonitzschia australis Frenguelli and related species from the west coast of the USA: occurrence and domoic acid production. J Shellfish Res 12:457-465

Villac MC, Roelke DL, Villareal TA, Fryxell GA (1993b) Comparison of two domoic acid-producing diatoms: a review. Hydrobiologia 269/270:213-224

Wiseman WJ Jr, Bierman VJ Jr, Rabalais NN, Turner RE (1992) Physical structure of the Louisiana shelf hypoxic region Texas Sea Grant Tech Rep 92-109, Galveston, p 21-26

Wood AM, Shapiro LP. Bates SS (1994) domoic acid, final report of the workshop, Oregon Institute of Marine Biology, Feb 21-23, 1992. Oregon Sea Grant Publ ORESU-W-94001. Corvalis

Work TM, Beale AM, Fritz L, Quilliam MA, Silver M, Buck K, Wright JLC (1993) Domoic acid intoxication of brown pelicans and cormorants in Santa Cruz, California. In: Smayda TJ, Shimizu Y (eds) Toxic phytoplankton blooms in the sea. Elsevier Science Publications, Amsterdam, p 643-649

Manuscript first received: April 9, 1996

Revised version accepted: October 15, 1996 